\title{
Caregivers' feeding style \& its relationship with nutritional status of preschool children in a rural area of West Bengal: A cross sectional study
}

\author{
Jayita Pal ${ }^{1}$, Arghya Kusum Pal ${ }^{2}$ \\ ${ }^{1}$ Tutor, Deptartment of Community Medicine, ESI-PGIMSR, ESIC Medical College, Joka, Kolkata, India \\ ${ }^{2}$ Registrar, Deptartment of Paediatrics and Neonatology, Belle Vue Clinic, Kolkata, India
}

\begin{abstract}
:
Background: Nutritional status of under-five children is dependent on various factors of which caregivers feeding technique is one of the major contributor. Responsive feeding in accordance to child's hunger cues with proper involvement of the caregivers can be an important factor in maintaining adequate growth and development of a child.

Methods: A cross sectional study had been conducted to assess the different feeding practices of the caregivers, nutritional status of 2-5years old children and the relationship of feeding styles and other relevant factors with malnutrition in Diara village among 102 child-caregiver dyad included in the study by complete enumeration method. The caregivers were interviewed after taking informed consent with the help of a predesigned pretested schedule. Nutritional status of the children was assessed using WHO ANTHRO software version 3.2.2. BMI had been calculated for every caregiver. Data were entered and analyzed by SPSS 20.0 software.

Results: The commonest feeding style was authoritative (47.1\%), followed by uninvolved (44.1\%), indulgent (5.9\%) and authoritarian type (2.9\%). Overall malnutrition among the children was $42.2 \%$. Multivariate analyses revealed malnutrition to be highly predominant in female child, when caregivers' education was low with BMI outside normal range and in case of indulgent and uninvolved feeding styles.

Conclusion: The study showed a positive association of caregivers' feeding techniques and nutritional status of the children in the study village. Further researches in large settings are the need of the hour to highlight this issue.
\end{abstract}

Key words: Caregiver, Feeding style, Nutritional status, Pre-school children, Rural

\section{Introduction:}

Childhood malnutrition still remains a major public health burden in India. Approximately staggering $42.5 \%$ of under-five Indian children are underweight while $48 \%$ are stunted and $19.8 \%$ are wasted according to NFHS 3. ${ }^{1}$ UNICEF says, along with food supply and access to health service, maternal care plays a fundamental role in shaping child's growth. ${ }^{2}$ Babies are highly vulnerable during the weaning period both in terms of nutrition and the caregivers' feeding techniques. An appropriate and safe complementary food along with correct behavior of the caregivers during feeding dictates the trajectory of child's growth and development. ${ }^{3,4}$ Responsive complementary feeding can be an ideal behavioral pattern when the caregiver correctly perceives and interprets child's hunger clues and signals. ${ }^{5}$ WHO guidelines for responsive feeding of non breastfed children includes following 5 steps: ${ }^{6}$

i. Feed children directly and assist older children when they fed themselves being sensitive to their hunger and satiety cues.

ii. Feed slowly and patiently encourage children to eat, don't force them.

iii. If children refuse many food, experiment with different food combination and tastes, textures and methods of encouragement

iv. Minimize distraction during meals.

v. Feeding times are periods of learning and love, talk to children during feeding with eye to eye contact.

Studies have been conducted relating parenting styles to the pattern of development of child's behavior which leads to change in different domains like cognitive, socio-emotional and health related areas. ${ }^{7}$ Parents change their feeding techniques according to specific health issues of their children. ${ }^{8}$ Home environment directs the child's future development. The styles of feeding during childhood play a pivotal role in determining the dietary habits and nutritional status of the child. ${ }^{9}$

Despite the fact that feeding style is often an important determinant of the child's nutritional status, studies depicting the relationship between the two are often in wanting. With this backdrop, the present study 
has been conducted to assess the different feeding patterns of the caregivers along with its predictors and the relationship of the feeding style with nutritional status of the children in a rural area of West Bengal.

\section{Methods:}

A community based cross-sectional study had been conducted in Diara village of Singur block, Hooghly district of West Bengal from December 2012 to February 2013. The study population constituted a total of 102 preschool children (2-5 years of age) and caregiver dyad. The person who is primarily taking care of the child including their feeding (biological mother/ other relative) was taken as 'caregiver' in this research. Out of the total 64 villages under the rural field practice area of All India Institute of Hygiene and Public Health, Diara Village was chosen randomly. Institutional ethical clearance was obtained before the study. Line listing of all the children aged 2-5 years was done with the help of health workers, then the subjects and their respective caregivers were included in the study after taking informed consent from the caregiver with due explanation about the importance of the study. Seriously ill subjects and children less than 2 years of age were excluded from the research because weaning takes up to 2 years for full establishment although it usually starts from 6 months of age.

The caregivers were interviewed with a predesigned and pretested schedule having two parts, the first part consisting of socio-demographic information and the other part was translated Caregiver's Feeding Style Questionnaire (CFSQ). CFSQ was translated in Bengali by a linguistic expert maintaining the semantic equivalence. To check the translation, it was retranslated back into English by two independent researchers who were unaware of the first English version. Reliability had been checked by test-retest method ( $\mathrm{r}=0.93)$. It had been pretested to see clarity, absence of any ambiguity, objectivity and simplicity. Necessary corrections were made and the schedule was then pilot tested from the neighborhood village that was not included in the study to get the final corrected schedule. CFSQ has a total of 19 questions. Demandingness and responsiveness dimensions are derived through 7 child-centered and 12 parent-centered feeding directives measured on a 5 point likert scale (scored as 1-5). Child-centered feeding is defined as directives that promote internalization of parental values (e.g., reasoning, complimenting and helping the child to eat) whereas parent-centered feeding is defined as directives that promote externalization or control of children's eating through external means (demands, threats and reward contingencies). A cross classification of high and low scores based on median splits on the 2 dimensions identifies four feeding styles: 1) Authoritative feeding style: high demandingness and high responsiveness 2) Authoritarian feeding style: high demandingness and low responsiveness 3) Indulgent: low demandingness and high responsiveness 4) Uninvolved: low demandingness and low responsiveness.

[Fig.1]

Height and weight of every child-caregiver dyad were taken. Nutritional status of the children had been assessed by using WHO ANTHRO software version 3.2.2, whereas BMI had been calculated for every caregiver. Data were entered and analyzed by SPSS 20.0 software.

\section{Results:}

The current research was done after interviewing 102 children (2-5 years of age)-caregiver dyads (mean age of children- $40.37 \pm 10.66$ months and mean age of caregivers $-26.94 \pm 6.49$ years). Majority of the caregivers were biological mothers $(75.5 \%)$. The subjects mostly belonged to Hindu religion $(66.7 \%)$, joint family $(57.8 \%)$ and middle class (38.2\%) according to Modified B.G. Prasad scale for the year 2012. Most of the children in the study were of first order $(48 \%)$. Male children constituted $52 \%$. Majority of the caregivers were housewives $(62.7 \%)$ and educated up to middle level $(33.3 \%)$.

Regarding the nutritional status of the children, $25.5 \%$ were underweight, $15.7 \%$ were severely underweight while $2 \%$ were overweight. Stunting was found in $16.7 \%$ of the children. Wasting was seen in $21.6 \%$ while $2.9 \%$ were severely wasted. Overall (using any of the criteria of WAZ/HAZ/WHZ) malnutrition among the children was $42.2 \%$. [Fig. 2]

As far as the nutritional status of the caregivers was concerned, $30.4 \%$ were underweight, $14.4 \%$ were overweight and $2 \%$ were obese.

The commonest feeding style found in this study was authoritative (47.1\%), followed by uninvolved (44.1\%), indulgent (5.9\%) and authoritarian type (2.9\%) [Fig. 3].

Bivariate analysis revealed bad score in CFSQ was predominantly high when the caregiver was other than the biological mother, age of the caregiver was above 23 years, having low educational background (up to primary level), engaged in works other than housework, with BMI outside normal range (WHO classification) and in female child with birth order above one. [Table1]

Regarding the determinants of malnutrition among study children, the factors found significant in bivariate analyses were included in two separate multivariate models.

The first model revealed malnutrition to be highly predominant in female child, when care-givers education was low with BMI outside normal range and in case of indulgent and uninvolved feeding styles. In 
second model, malnutrition was found to be significantly higher among female child, if BMI of caregiver was outside normal range with authoritarian and uninvolved feeding styles. [Table2]

\section{Discussion:}

Present study revealed authoritative feeding style was the most common among the caregivers followed by the uninvolved type where as other researchers like Hughes SO et al ${ }^{10,11}$ showed indulgent and authoritative feeding style being most common.

Previous researches ${ }^{11}$ showed a consistent positive relationship between indulgent feeding style and children weight status in the families with low economic status; while the current study showed indulgent and uninvolved type of feeding to be significantly associated with occurrence of malnutrition in children of Diara village.

Researches done in developed countries showed varied results with the relationship between child adiposity and caregivers feeding style. Few studies revealed no relationship between the two ${ }^{12,13,14}$; whereas some researchers found parents encouraging leaner children to eat more than children they perceive to be overweight. Francis et $\mathrm{al}^{15}$ reported forceful feeding of underweight daughters by their mothers. Spruijt-Metz et al. suggested that a caregiver's concern for a child's weight and pressure to eat were directly related to the child's total fat mass. ${ }^{16}$

In a developing country like India, though overweight and obesity are the upcoming public health issue, still undernutrition occupies a major portion of the sphere. But researches relating the caregivers' feeding practice with undernourishment of the children are still a few.

Regarding the nutritional status of the children of Diara village, $25.5 \%$ were underweight, $15.7 \%$ were severely underweight. Stunting was found in $16.7 \%$ of the children. Wasting was seen in $21.6 \%$ while $2.9 \%$ were severely wasted. The above figures were somehow different as compare to NFHS 3 which showed under nutrition and severe undernutrition to be $45.6 \%$ and $17.5 \%$ respectively, stunting and severe stunting to be $50.7 \%$ and $25.6 \%$ respectively, while wasting and severe wasting to be $20.7 \%$ and $6.7 \%$ respectively among under-five children in rural India. This contrast in difference might be reflected due to the fact that the current study considered the age group of 2-5 years.

Though parenting style is a major regulator of child's nutritional status, there are other factors contributing to the same. The current study revealed a positive relationship between caregivers BMI and child's weight status. Caregivers either underweight or overweight were noncompliant to physical activity which was essential for responsive feeding of the children. Female sex and low education of the caregivers were the other two factors significantly contributing to malnutrition among the children of Diara village.

The researchers of the current study were not funded by any external source and hindered by time constraints. As a result of which the study was undertaken among the children of only one village of West Bengal constituting a small sample size. Despite these limitations, overall findings provided evidence to establish the pattern of feeding style of caregivers and vis a vis the relationship of nutritional status with feeding pattern.

\section{Conclusion:}

Young children are dependent on caregivers for feeding, making parenting style a big factor influencing child's nutritional status. The influence is bidirectional and the dynamics between the care giver and child dyad should be taken into reference especially interpreting evidence from observational, cross sectional study.

This study added to the growing body of literature on feeding style and childhood nutritional outcome. Nearly half of the children under the present study were found to be malnourished. The majority of care givers were practicing authoritative type of feeding practice, but uninvolved feeding style was also practiced by almost half of them which showed a positive relationship with malnutrition among the children of Diara village. Being in this kind of alarming situation, caregivers should be educated through proper IEC to change the practice to ensure proper growth and development. Community based nutrition education and intervention programme should be adopted to change the beliefs, attitudes and practices of the caregivers.

\section{References:}

[1]. International institute of Population Sciences (IIPS) and Macrointernational, 2007, National Family Health Survey ( NFHS-3) 200506, India, Vol 1. http:/nfhsindia.org/nfhs3_national_report.html last accessed on Dec 24. 2012.

[2]. UNICEF policy review. Strategy for improved nutrition of children and women in developing countries. 1990 [cited; Available from: http://www.ceecis.org/iodine/01_global/01_pl/01_01_other_1992_unicef.pdf last accessed on Dec 24. 2012.

[3]. Pelto GH, Levitt E, Thairu L. Improving feeding practices: Current patterns common constraints, and the design of interventions. Food and Nutrition Bulletin. 2003;24:45-82.

[4]. Engle PL, Bentley M, Pelto G. The role of care in nutrition programmes: current research and a research agenda. Proceedings of the Nutrition Society. 2000;59:25-35. 
[5]. Aboud FE, Moore AC, Akhter S. Effectiveness of a community-based responsive feeding programme in rural Bangladesh: a cluster randomized field trial. Maternal and Child Nutrition. 2008;4: 275-286.

[6]. World Health Organization. Guiding principles for feeding non-breastfed children 6 - 24 months of age. Department of Child and Adolescent Health and Development. 2005.

[7]. Steinberg L. Beyond the Classroom: Why School Reform has Failed and what Parents Need to Do. New York, NY: Simon \& Schuster; 1996.

[8]. Costanzo PR, Woody EZ. Domain-specific parenting styles and their impact on the child's development of particular deviance: the example of obesity proneness. J Soc Clin Psychol. 1985;4:425-445.

[9]. Davison KK, Birch LL. Childhood overweight: a contextual model and recommendations for future research. Obes Rev 2001; 2: $159-71$.

[10]. Hughes SO, Patrick H, Thomas G., Jennifer O. , Cheryl B., Theresa A. The Impact of Child Care Providers' Feeding on Children's Food Consumption. Journal of Developmental \& Behavioral Pediatrics. 2007;28(2):100-107

[11]. Hughes SO, Shewchuk RM, Baskin ML. Theresa A. Indulgent Feeding Style and Children's Weight Status in Preschool. Journal of Developmental \& Behavioral Pediatrics. 2008;29(5):403-410

[12]. Baughcum AE, Powers SW, Johnson SB, Chamberlin LA, Deeks CM, Jain A, Whitaker RC. Maternal feeding practices and beliefs and their relationships to overweight in early childhood. Journal of Developmental and Behavioral Pediatrics. 2001;22:391-408.

[13]. May AL, Donohue M, Scanlon KS, Sherry B, Dalenius K, Faulkner P, Birch LL. Child-feeding strategies are associated with maternal concern about children becoming overweight, but not children's weight status. Journal of the American Dietetic Association. 2007; 107:1167-1174.

[14]. Drucker RR, Hammer LD, Agras WS, Bryson S. Can mothers influence their child's eating behavior? Journal of Developmental and Behavioral Pediatrics. 1999;20:88-92.

[15]. Francis LA, Hofer SM, Birch LL. Predictors of maternal child-feeding style: maternal and child characteristics. Appetite. 2001;37:231-243.

[16]. Spruijt-Metz D, Lindquist CH, Birch LL, Fisher JO, Goran MI. Relation between mothers' child-feeding practices and children's adiposity. American Journal of Clinical Nutrition. 2002;75:581-586.

Figure 1: Feeding styles of the caregivers

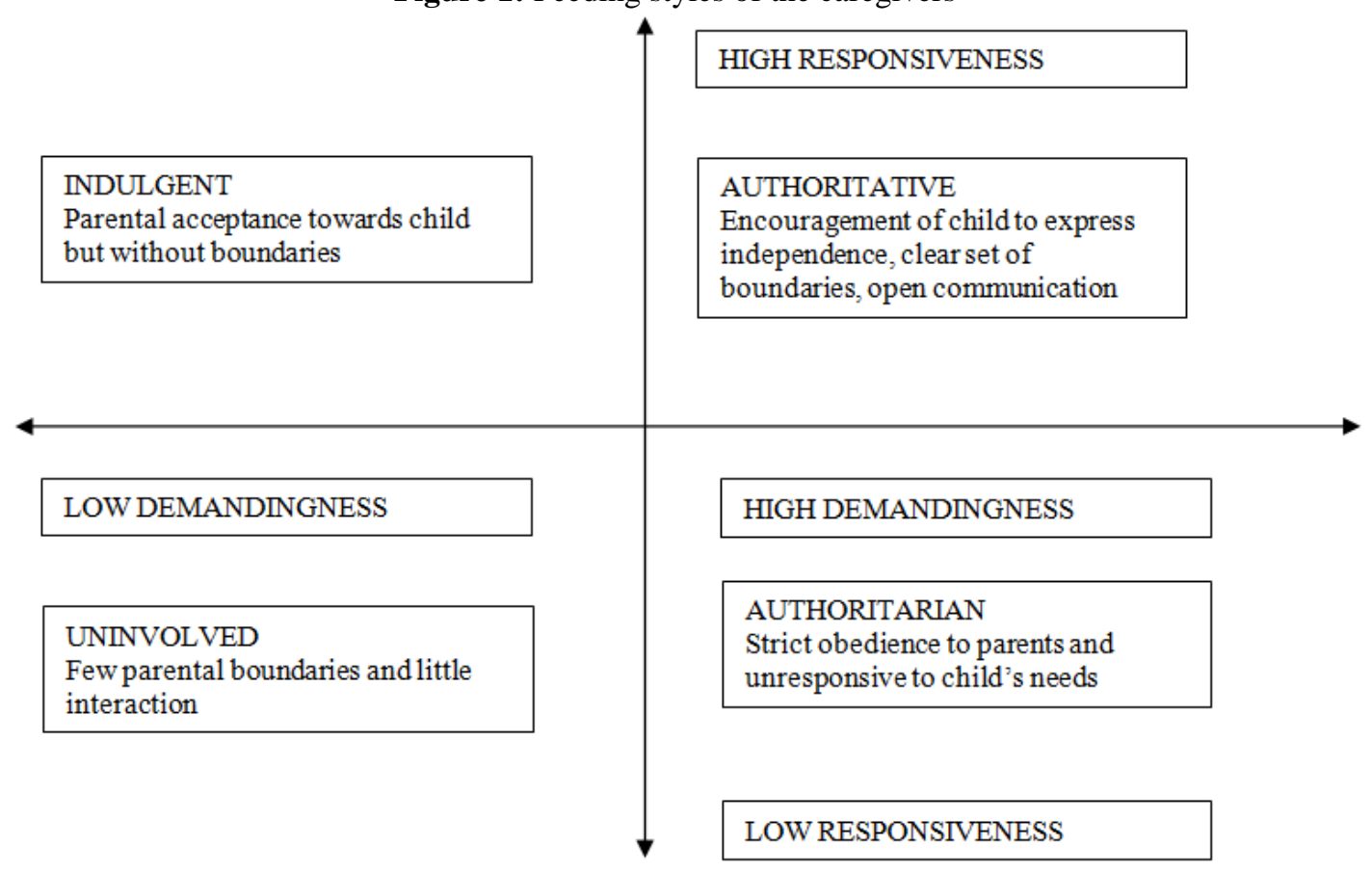


Caregivers' feeding style \& its relationship with nutritional status of preschool children in a ....

Figure 2: Distribution of nutritional status of the children according to different criteria $(\mathrm{N}=102)$

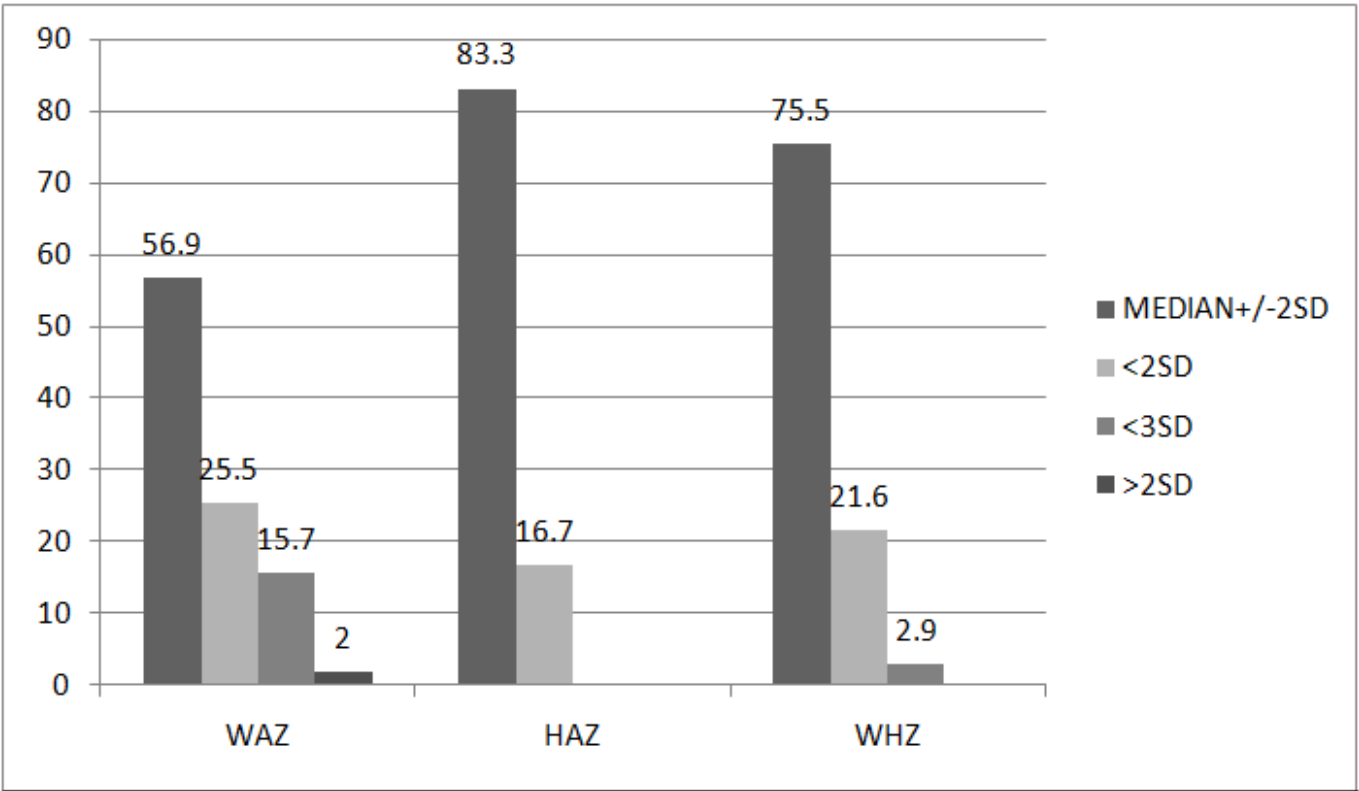

WAZ=weight for age $\mathrm{Z}$ score, $\mathrm{HAZ}=$ height for age $\mathrm{Z}$ score, $\mathrm{WHZ}=$ weight for height $\mathrm{Z}$ score

Figure 3: Distribution of caregivers according to different feeding styles $(\mathrm{N}=102)$

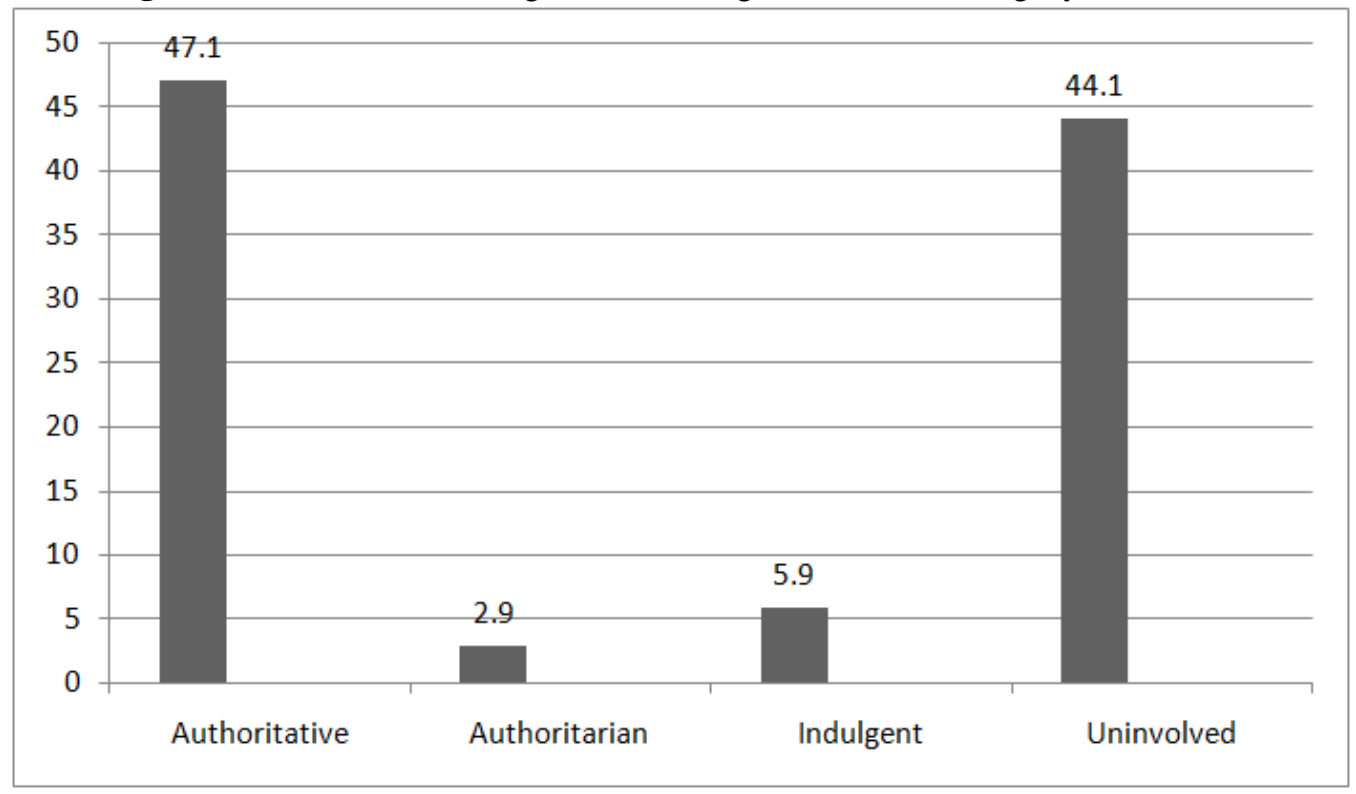

Table-1: Distribution of caregivers according to score obtained through CFSQ and different socio-demographic

\begin{tabular}{|c|c|c|c|}
\hline Variable (No) & $\begin{array}{l}\text { Bad score in CFSQ } \\
\left(<66^{*}\right) \\
\mathrm{NO}(\%)\end{array}$ & Test of significance & $\mathrm{OR}(\mathrm{CI})$ \\
\hline $\begin{array}{l}\text { Age of caregiver } \\
>=24 * \text { years }(56) \\
<24 \text { years }(46)\end{array}$ & $\begin{array}{l}39(69.6) \\
12(26.1) \\
\end{array}$ & $\begin{array}{l}\text { Chi-square }=19.165, \mathrm{df}=1, \\
\mathrm{P}=0.000\end{array}$ & $6.5(2.722-15.521)$ \\
\hline $\begin{array}{l}\text { Age of child } \\
>=42 * \text { months }(56) \\
<42 \text { months }(46)\end{array}$ & $\begin{array}{l}31(55.4) \\
20(43.5) \\
\end{array}$ & $\begin{array}{l}\text { Chi-square }=1.425, \mathrm{df}=1, \\
\mathrm{P}=0.233\end{array}$ & $1.612(0.735-3.537)$ \\
\hline $\begin{array}{l}\text { Type of caregiver } \\
\text { Others(25) } \\
\text { Biological mother(77) }\end{array}$ & $\begin{array}{l}20(80.0) \\
31(40.3)\end{array}$ & $\begin{array}{l}\text { Chi-square }=11.922, \mathrm{df}=1, \\
\mathrm{P}=0.001\end{array}$ & $5.935(2.014-17.489)$ \\
\hline $\begin{array}{l}\text { Sex of child } \\
\text { Female(49) } \\
\text { Male(53) }\end{array}$ & $\begin{array}{l}34(69.4) \\
17(32.1) \\
\end{array}$ & $\begin{array}{l}\text { Chi-square }=14.179, \mathrm{df}=1, \\
\mathrm{P}=0.000\end{array}$ & $4.8(2.077-11.093)$ \\
\hline
\end{tabular}


Caregivers' feeding style \& its relationship with nutritional status of preschool children in a ....

\begin{tabular}{|c|c|c|c|}
\hline $\begin{array}{l}\text { Order of the child } \\
>=2^{\text {nd }} \text { order } *(53) \\
1^{\text {st }} \text { order }(49)\end{array}$ & $\begin{array}{l}37(69.8) \\
14(28.6)\end{array}$ & $\begin{array}{l}\text { Chi-square }=17.321, \mathrm{df}=1, \\
\mathrm{P}=0.000\end{array}$ & $5.781(2.463-13.570)$ \\
\hline $\begin{array}{l}\text { Education of the caregiver } \\
\text { Up to primary }(43) \\
\text { Middle \& above(59) }\end{array}$ & $\begin{array}{l}35(81.4) \\
16(27.1)\end{array}$ & $\begin{array}{l}\text { Chi-square }=29.309, \mathrm{df}=1 \text {, } \\
\mathrm{P}=0.000\end{array}$ & $11.758(4.507-30.672)$ \\
\hline $\begin{array}{l}\text { Occupation of the caregiver } \\
\text { Engaged in work other than HW(38) } \\
\text { Housework(64) }\end{array}$ & $\begin{array}{l}27(71.1) \\
24(37.5) \\
\end{array}$ & $\begin{array}{l}\text { Chi-square }=10.737, \mathrm{df}=1 \text {, } \\
\mathrm{P}=0.001\end{array}$ & 4.091 (1.723-9.712) \\
\hline $\begin{array}{l}\text { Type of family } \\
\text { Nuclear(43) } \\
\text { Joint }(59)\end{array}$ & $\begin{array}{l}26(60.5) \\
25(42.4)\end{array}$ & $\begin{array}{l}\text { Chi-square }=3.257, \mathrm{df}=1, \\
\mathrm{P}=0.071\end{array}$ & $2.080(0.934-4.630)$ \\
\hline $\begin{array}{l}\text { Religion } \\
\text { Muslim(34) } \\
\text { Hindu(68) }\end{array}$ & $\begin{array}{l}19(55.9) \\
32(47.1)\end{array}$ & $\begin{array}{l}\text { Chi-square }=0.706, \mathrm{df}=1, \\
\mathrm{P}=0.401\end{array}$ & $1.425(0.623-3.260)$ \\
\hline $\begin{array}{l}\text { Socio-economic status } \\
\text { Low(lower middle \& lower) (43) } \\
\text { High (59) }\end{array}$ & $\begin{array}{l}23(53.5) \\
28(47.5)\end{array}$ & $\begin{array}{l}\text { Chi-square }=0.362, \mathrm{df}=1, \\
\mathrm{P}=0.547\end{array}$ & $1.273(0.579-2.798)$ \\
\hline $\begin{array}{l}\text { BMI for age of the caregiver } \\
\text { Not normal ( under nutrition } \\
\text { /overweight/obese)(48) } \\
\text { Normal(54) }\end{array}$ & $\begin{array}{l}39(81.2) \\
12(22.2)\end{array}$ & $\begin{array}{l}\text { Chi-square }=33.095, \mathrm{df}=1 \text {, } \\
\mathrm{P}=0.000\end{array}$ & 15.167(5.761-39.927) \\
\hline
\end{tabular}

*median

Table-2: Determinants of under nutrition: Bivariate and Multivariate analyses $(n=102)$

\begin{tabular}{|c|c|c|c|c|c|}
\hline \multirow[t]{2}{*}{ Variable (No) } & \multirow{2}{*}{$\begin{array}{l}\text { Malnutrition } \\
\text { No }(\%)\end{array}$} & \multirow[t]{2}{*}{ Test of significance } & \multirow[t]{2}{*}{$\mathrm{OR}(\mathrm{CI})$} & \multicolumn{2}{|c|}{$\mathrm{AOR}(\mathrm{CI})$} \\
\hline & & & & Model 1 & Model 2 \\
\hline $\begin{array}{l}\text { Age of caregiver } \\
>=24 * \text { years }(56) \\
<24 \text { years }(46)\end{array}$ & $\begin{array}{l}33(58.9) \\
10(21.7)\end{array}$ & $\begin{array}{l}\text { Chi-square }=14.234, \mathrm{df}=1 \text {, } \\
\mathrm{P}=0.000\end{array}$ & $\begin{array}{l}5.165 \\
(2.143- \\
12.452)\end{array}$ & $\begin{array}{l}2.938(0.739- \\
11.677)\end{array}$ & $\begin{array}{l}2.462(0.651- \\
9.314)\end{array}$ \\
\hline $\begin{array}{l}\text { Age of child } \\
>=42 * \text { months }(56) \\
<42 \text { months }(46)\end{array}$ & $\begin{array}{l}25(44.6) \\
18(39.1)\end{array}$ & $\begin{array}{l}\text { Chi-square }=0.315, \mathrm{df}=1 \text {, } \\
\mathrm{P}=0.575\end{array}$ & $\begin{array}{l}1.254 \\
(0.568- \\
2.771)\end{array}$ & - & - \\
\hline $\begin{array}{l}\text { Type of caregiver } \\
\text { Others( } 25) \\
\text { Biological mother(77) }\end{array}$ & $\begin{array}{l}16(64.0) \\
27(35.1) \\
\end{array}$ & $\begin{array}{l}\text { Chi-square }=6.480, \mathrm{df}=1, \\
\mathrm{P}=0.011\end{array}$ & $\begin{array}{l}3.292 \\
(1.284- \\
8.439) \\
\end{array}$ & $\begin{array}{l}0.803(0.191- \\
3.380)\end{array}$ & $\begin{array}{l}0.719(0.165- \\
9.314)\end{array}$ \\
\hline $\begin{array}{l}\text { Sex of child } \\
\text { Female(49) } \\
\text { Male(53) }\end{array}$ & $\begin{array}{l}32(65.3) \\
11(20.8)\end{array}$ & $\begin{array}{l}\text { Chi-square }=20.724, \mathrm{df}=1, \\
\mathrm{P}=0.000\end{array}$ & $\begin{array}{l}7.187 \\
(2.960- \\
17.449)\end{array}$ & $\begin{array}{l}4.352(1.270- \\
14.912)\end{array}$ & $\begin{array}{l}4.593(1.326- \\
15.911)\end{array}$ \\
\hline $\begin{array}{l}\text { Order of the child } \\
>=2^{\text {nd }} \text { order } *(53) \\
1^{\text {st }} \text { order }(49)\end{array}$ & $\begin{array}{l}32(60.4) \\
11(22.4)\end{array}$ & $\begin{array}{l}\text { Chi-square }=15.020, \mathrm{df}=1, \\
\mathrm{P}=0.000\end{array}$ & $\begin{array}{l}5.264 \\
(2.210- \\
12.539) \\
\end{array}$ & $\begin{array}{l}2.991(0.807- \\
11.084)\end{array}$ & $\begin{array}{l}3.021(0.812- \\
11.242)\end{array}$ \\
\hline $\begin{array}{l}\text { Education of the caregiver } \\
\text { Up to primary }(43) \\
\text { Middle \& above }(59)\end{array}$ & $\begin{array}{l}30(69.8) \\
13(22.0)\end{array}$ & $\begin{array}{l}\text { Chi-square }=23.241, \mathrm{df}=1 \text {, } \\
\mathrm{P}=0.000\end{array}$ & $\begin{array}{l}8.166 \\
(3.334- \\
20.001)\end{array}$ & $\begin{array}{l}4.622(1.106- \\
19.314)\end{array}$ & $\begin{array}{l}3.121(0.699- \\
13.938)\end{array}$ \\
\hline $\begin{array}{l}\text { Occupation of the caregiver } \\
\text { Other than housework(38) } \\
\text { Housework(64) }\end{array}$ & $\begin{array}{l}22(57.9) \\
21(32.8)\end{array}$ & $\begin{array}{l}\text { Chi-square= 6.151, } \mathrm{df}=1, \\
\mathrm{P}=0.013\end{array}$ & $\begin{array}{l}2.815 \\
(1.229- \\
6.449) \\
\end{array}$ & $\begin{array}{l}0.672(0.176- \\
2.566)\end{array}$ & $\begin{array}{l}0.571(0.143- \\
2.291)\end{array}$ \\
\hline $\begin{array}{l}\text { Type of family } \\
\text { Nuclear(43) } \\
\text { Joint(59) }\end{array}$ & $\begin{array}{l}19(44.2) \\
24(40.7)\end{array}$ & $\begin{array}{l}\text { Chi-square }=0.126, \mathrm{df}=1, \\
\mathrm{P}=0.723\end{array}$ & $\begin{array}{l}1.155 \\
(0.521- \\
2.557)\end{array}$ & - & - \\
\hline $\begin{array}{l}\text { Religion } \\
\text { Muslim(34) } \\
\text { Hindu(68) }\end{array}$ & $\begin{array}{l}17(50.0) \\
26(38.2)\end{array}$ & $\begin{array}{l}\text { Chi-square }=1.287, \mathrm{df}=1, \\
\mathrm{P}=0.257\end{array}$ & $\begin{array}{l}1.615 \\
(0.703- \\
3.710)\end{array}$ & - & - \\
\hline $\begin{array}{l}\text { Socio-economic status } \\
\text { Low (lower middle \& lower) (43) } \\
\text { High (59) }\end{array}$ & $\begin{array}{l}19(44.2) \\
24(40.7)\end{array}$ & $\begin{array}{l}\text { Chi-square }=0.126, \mathrm{df}=1, \\
\mathrm{P}=0.723\end{array}$ & $\begin{array}{l}1.155 \\
(0.521- \\
2.557)\end{array}$ & - & - \\
\hline $\begin{array}{l}\text { BMI for age of the caregiver } \\
\text { Not normal* }(48) \\
\text { Normal }(54)\end{array}$ & $\begin{array}{l}34(70.8) \\
9(16.7)\end{array}$ & $\begin{array}{l}\text { Chi-square }=30.576, \mathrm{df}=1, \\
\mathrm{P}=0.000\end{array}$ & $\begin{array}{l}12.143 \\
(4.703- \\
31.349) \\
\end{array}$ & $\begin{array}{l}4.279(1.085- \\
16.871)\end{array}$ & $\begin{array}{l}3.229(0.763- \\
13.654)\end{array}$ \\
\hline $\begin{array}{l}\text { Feeding style (demandingness) } \\
\text { Indulgent and uninvolved (51) } \\
\text { Authoritative and authoritarian (51) }\end{array}$ & $\begin{array}{l}36(70.6) \\
7(13.7)\end{array}$ & $\begin{array}{l}\text { Chi-square }=33.812, \mathrm{df}=1, \\
\mathrm{P}=0.000\end{array}$ & $\begin{array}{l}15.086 \\
(5.553- \\
40.984)\end{array}$ & $\begin{array}{l}2.502(1.285- \\
7.916)\end{array}$ & - \\
\hline $\begin{array}{l}\text { Feeding style (responsiveness) } \\
\text { Authoritarian } \\
\text { and uninvolved (48) } \\
\text { Authoritative and Indulgent (54) }\end{array}$ & $\begin{array}{l}36(75.0) \\
7(13.0)\end{array}$ & $\begin{array}{l}\text { Chi-square }=40.107, \mathrm{df}=1, \\
\mathrm{P}=0.000\end{array}$ & $\begin{array}{l}20.143 \\
(7.204- \\
56.324)\end{array}$ & - & $\begin{array}{l}3.597(1.705- \\
18.360)\end{array}$ \\
\hline
\end{tabular}

Model 1- Nagelkerke R Square - 0.615, Hosmer and Lemeshow Test $(\mathrm{p}=0.662)$

Model 2- Nagelkerke R Square -0.630, Hosmer and Lemeshow Test ( $\mathrm{p}=0.581)$

*(under nutrition /overweight/obese) 